\title{
An Assessment of the Environmental Impact, Risk Challenges and Mitigation Strategies in Ameka Illegal Mine Sites and Environs in Ebonyi State, Southeastern Nigeria
}

\author{
Solomon Okechukwu Amadi ${ }^{1 *}$, Timothy Onyekachi Chigbu ${ }^{2}$ \\ ${ }^{1}$ Department of Physics, Geology and Geophysics, Alex Ekwueme Federal University Ndufu-Alike, Ebonyi State, Nigeria \\ ${ }^{2}$ Department of Physics and Electronics, Abia State Polytechnic, Aba, Abia State, Nigeria
}

Corresponding Author Email: solomonokeamadi@gmail.com

https://doi.org/10.18280/eesrj.070205

Received: 12 March 2020

Accepted: 9 April 2020

\section{Keywords:}

atomic absorption spectrometer, environmental degradation, environmental management, heavy metals concentrations, Mitigation, $\mathrm{pH}$

\begin{abstract}
This study was undertaken to assess the environmental impact of illegal mining and their associated risks in Ameka illegal mining sites and environs in Ebonyi State, Nigeria. The approach to the study involved direct personal observations, oral interviews and laboratory analyses of water and soil samples obtained from the mapped areas around the vicinity of the mining sites. Soil and water samples around non-mining sites were obtained to serve as control. Atomic Absorption Spectrometer (AAS) was used to quantify the levels of $\mathrm{pH}$ and heavy metal contaminations of the water and soil samples. Digital camera was used to capture scenes at some mining sites. The laboratory results show that lead concentrations and $\mathrm{pH}$ in water samples in the areas are outside the World Health Organization (WHO) permissible limit for domestic water use. The heavy metal concentration and $\mathrm{pH}$ in the soils in the mapped area fall within the recommended tolerable limit set by WHO but clearly higher than that of the control. Mining activities were executed without recourse to the existing regulations. The results exposed the level of soil and water contamination in the mining areas and the resulting biophysical, health, and socio-economic consequences. This could motivate the host community to take proactive measures to curtail the risks.
\end{abstract}

\section{INTRODUCTION}

Illegal mining is a serious problem threatening the landscape of the host communities. The serious impact of surface mining on the topography, vegetation and water resources have made it highly controversial. Surface mining is subject to the federal and state reclamation requirements. Unless reclaimed, surface mining can leave behind large areas of infertile waste earth materials. The process has engendered numerous environmental problems of which mitigation practices have not been adequately addressed. This study was carried out to assess the environmental impact of illegal mining in the context of environmental management.

Palmer et al. [1] had observed that the destruction of large tracts of deciduous forests and fertile grasslands has threatened several endangered species and led to biodiversity challenges. Some studies have shown that different important minerals occur in every State of Nigeria, including gold, iron, lead, kaolin, limestone, granite, zinc, uranium, columbite and phosphate to mention a few $[2,3]$. Surface mining is a broad category of mining in which the overburden is removed in an effort to extract valuable minerals and other earth materials. Squillace [4] described types of surface mining to include strip mining, open-cast mining, contour mining and mountain-top removal. Surface mining is now the predominant form of mining of solid minerals. The predominant solid minerals in the study area are the sulphides of zinc and lead. Terrains, economics, customs and the physical characteristics of the sought raw materials dictate the technique available to an operator. All surface mining operations have destructive effects on the environment and the shear volume of materials involved make the impact on the environment particularly acute. The environmental implications vary in magnitude of severity in the short or long run, ranging from environmental degradation, ecosystem depletion, contamination of surface and subsurface water reservoirs, erosion and flooding, consequent upon extensive landscape disruption. Moreover, development and widening of cracks in buildings, settlement destabilization and earth tremors are usually associated with severe mining operations.

Because major disruption of the earth's surface is inevitable, environmental impact assessment (EIA) is carried out prior to the commencement of the actual operations. Even after the commencement of the mining processes, environmental audits are carried out periodically on the host environment. The environmental management systems auditing is a procedure for periodic, systematic, documented and objective evaluation of an organization's requirements. It entails the assessment of the organization's compliance with its policies, procedures and regulatory requirements with the ultimate aim of facilitating management control of environmental practices (including environmental protection and prevention of pollution) in tandem with the socioeconomic needs and environmental best practices. In the case of illegal miners, these issues are absolutely not considered. Even with regulations governing the mining activities by regulating agencies (such as the Federal Ministry of Environment, State Environmental Protection Agencies, Federal and State Ministries of Health and Federal Ministry of Solid Minerals Development), the actions of the illegal miners 
are suggestive of the fact that the rules are not meant for them. Their activities continue unabated, and they ignore the laws with impunity and continue to exploit the environment with reckless abandon. Hence their activities are illegal.

The illegal miners in Nigeria are mostly rural and poor people usually working without legal mining titles or mining concession rights. They operate without recourse to government regulations and controls. The activities are carried out with simple, portable tools and sometimes heavy equipment. The few modern tools used include rock blaster and water pumping machine for draining water out of the mining pits. The array of activities is unregulated and uncoordinated, resulting in haphazard extraction of the minerals and eventual destruction of the environment. United Nations Environmental Programme (UNEP) [5] in Adekeye [3] characterized illegal mining by the following parameters: reduced degree of mechanization; great amount of physically demanding work; low level of productivity; low level of occupational safety and health care; insufficient consideration for environmental issues; and working without legal mining title. According to Jaiye [2], different types of intoxicants are taken orally or injected into the bodies of the young miners who work like machines tirelessly. When the economic potential of the mines shrink, they are usually abandoned without any attempt at rehabilitation.

The area under study is dominated by illegal artisanal mining that leads to heavy metal contamination in soil and water [6]. Pollution from these activities reaches critical levels and poses health risks for residents within the vicinity and environs [7]. Often, artificial lakes result from the mining activity. Moore et al. [8] posited that lakes and other surface water bodies are susceptible to anthropogenic contamination without clear signs unless in the clear cases of euthrophication. Kishe and Machiwa [9] and Farkas et al. [10] further stated that heavy metals are among the leading toxic and persistent pollutants that accumulate in aquatic environments, with increased concentration through the process of biomagnification. According to Authman et al. [11], lead is among the heavy metals that has most carcinogenic effects, and has been observed to cause neurological impairment and malfunctioning of the central nervous system. Lead and zinc, like other heavy metals, are naturally present in the earth's crust. However, human exposure and contamination arise from the mining of the ores and subsequent processing [6]. Mining drainage sources also has the tendency to increase the metal load in natural water sources [12].

Study by Ogunbanjo et al. [13] reported that the uptake of heavy metals from the soil by plants is inevitable, although the uptake varies according to plant species while indicated that heavy metal can cause toxicity in varying degrees in humans [14]. The contamination of the mining environment with heavy metals and the associated hazards makes the study of this nature very significant in agrarian rural communities lacking in proper orientation. Some studies have been carried out within the Abakaliki-Enyigba-Ikwo lead-zinc deposits of Ebonyi State Nigeria. Obasi et al. [15] evaluated heavy metals contamination in soils and vegetables and the associated human risks in Enyigba. Obarezi and Nwosu [16] examined the structural controls of lead-zinc mineralization of Enyigba. Alo et al. [17] assessed the effects of lead-zinc mining in soil and water quality in Ameka between 2012 and 2013 on the basis of heavy metal contamination and physicochemical properties of soil and water. This study is the only study in Ameka community though it did not extend to the neighbouring communities. The study area is an agrarian community in which a large section of the populace were farmers with subsistence orientation prior to the paradigmatic shift to lead-zinc mining for some years now which appears to have contributed stupendously to the economic development of the area. With the paradigmatic shift to the lead-zinc mining and the exacerbation tendencies, there is the need for a timelapse return of the assessment of the lead-zinc mining impact in Ameka and environs while incorporating other biophysical impacts and measures for mitigation in the present study. The indigenous population may be ignorant of the far-reaching consequences, being contented with the quick income they make from the activity. These people need to be exposed to the associated risks through research, while inculcating in their minds the necessary measures to curtail the risks

This study is aimed at assessing the illegal mining activities in Ameka mining sites and environs in Ebonyi State Nigeria with respect to their biophysical, health and socio-economic impact. It assessed the effect of mining on the $\mathrm{pH}$ and heavy metal contamination of water resources and arable soil within the area and environs. The implications of improper disposal of waste rocks, acid mine drainage, deforestation, use of explosives and changes in land use on the host community are highlighted. The work provides remedial recommendations that would assist the environmental managers and decision makers in policy formulation and capacitation.

The remaining parts of the paper is organized in the following sequence: Study area, Methodology, Results and Discussion, Other biophysical impacts, Associated challenges, Mitigation options, Conclusion, References and Nomenclature.

\section{STUDY AREA}

The study area coordinates on Longitude $8^{\circ} \mathrm{E}$ and Latitude $6^{\circ} \mathrm{N}$. The area is an agrarian rural community with rich lead and zinc deposits and lies within Ikwo and Ezza South Local Government Areas of Ebonyi State in Southeastern Nigeria. The area is located within the Lower Benue Trough sedimentary basin of Nigeria. The Trough extends from about $6^{\circ} \mathrm{N}$ in the southern part of the country to about $10^{\circ} \mathrm{N}$ in the Middle Belt region where it adjoins the Lake Chad Basin. The Trough is terminated to the Southeast by the Calabar Urban Massifs. The area falls within the tropical rainforest agroecological zone of Nigeria which has an annual total rainfall in the range of $2.000 \mathrm{~mm}$ to $3.000 \mathrm{~mm}$ or more [18]. The rural populace are predominantly farmers with subsistence orientation. They use their farmlands within the mining vicinity for their farming activities which is their main source of livelihood. There is a paradigmatic shift to lead-zinc mining presently by a reasonable percentage of the populace.

\section{METHODOLOGY}

Oral interviews with the miners and indigenes of the locality were conducted to elicit responses. Surface water, groundwater and soil samples in the area were collected from different mapped locations in the study area for analyses. Soil samples were collected at a distance range of 200 to 500 metres away from the mine sites at a depth of 0.3 metre. The 0.3 metre depth was deemed satisfactory for the purpose of characterizing the cultivatable top soil. Laboratory analysis of samples of water and soil were carried out to quantify the 
heavy metal concentration and the hydrogen ion concentration (pH). Heavy metal content and $\mathrm{pH}$ analyses were done at The Abia State Polytechnic, Aba, Abia State Nigeria using the atomic absorption spectrometer (AAS). Published materials were used to lend support to the laboratory analysis whereas a digital camera was used to capture some scenes in the mine area.

\section{RESULTS AND DISCUSSION}

Table 1 is the result of the heavy metal contents in $\mathrm{mg} / \mathrm{L}$ of the water samples and their corresponding $\mathrm{pH}$ values. The concentration of lead in the water samples range from 0.06 to $0.29 \mathrm{mg} / \mathrm{L}$. The samples from surface water (pond) and subsurface water (borehole) located within $500 \mathrm{~m}$ away from the Ameka and Ohankwu mines have high lead concentration as shown in Table 1. The Ohankwu and Ameka mine waters have high lead concentration of 0.58 and $0.29 \mathrm{mg} / \mathrm{L}$ respectively. These values in Table 1 are above the maximum tolerable limit of $0.05 \mathrm{mg} / \mathrm{L}$ recommended by World Health Organisation (WHO) and Food and Agricultural Organisation (FAO) for drinking water [19]. These values are clearly higher than that of the control borehole $(0.009 \mathrm{mg} / \mathrm{L})$. The results demonstrate the profound negative influence of unregulated mining activities in generating heavy metal contamination of water resources in the area. There is the tendency that the domestic water resources would be contaminated by lead and constitute a severe health threat to the inhabitants in the area. Lead concentration in the mine area portrays inherent danger if it finds its way to the domestic water resources because it would probably exceed the maximum permissible level depending on the location of the mine away from the domestic water source. This is because the heavy metal concentration and toxicity potentials decease with increasing distance from the mines. Zinc concentrations of water samples in the area are in the range of $1.21 \mathrm{mg} / \mathrm{L}$ to $0.41 \mathrm{mg} / \mathrm{L}$ which is below the maximum tolerable limit of $15 \mathrm{mg} / \mathrm{L}$ for domestic water use recommended by FAO and WHO [14]. The $\mathrm{pH}$ values of the samples indicated in Table 1 reveals acidic conditions and falls outside the range of $6.5-7.5$ permissible limits for domestic water according to $\mathrm{WHO}$ recommendation.

Table 1. Results of heavy metal concentration in $\mathrm{mg} / \mathrm{L}$ and $\mathrm{pH}$ of water samples

\begin{tabular}{ccccc}
\hline Location & Source & $\begin{array}{c}\text { Lead } \\
(\mathbf{P b})\end{array}$ & $\begin{array}{c}\text { Zinc } \\
(\mathbf{Z n})\end{array}$ & $\mathbf{p H}$ \\
\hline Ameka & Pond & 0.15 & 0.265 & 6.48 \\
Ameka & Mine water & 0.29 & 0.41 & 6.32 \\
Ameka & Borehole & 0.06 & 0.21 & 6.35 \\
Ohankwu & Pond & 0.13 & 0.34 & 6.76 \\
Ohankwu & Well & 0.15 & 0.195 & 6.58 \\
Ohankwu & Mine water & 0.58 & 1.21 & 6.20 \\
Abakaliki & Borehole & 0.009 & 0.053 & 7.04 \\
(Control) & & & & \\
\hline
\end{tabular}

Table 2 shows that the concentration of heavy metals in the soils within $500 \mathrm{~m}$ distance away from the mine pits fall within the recommended tolerable limit set by WHO. Nevertheless, the heavy metals concentrations around the mine area are above that of the control. The $\mathrm{pH}$ values of the soil samples indicate that they are within the acceptable limits set by WHO.

The results show that unregulated exploitation of the ore minerals would create some debilitating effects on the host community, notably by contamination of arable lands and domestic water resources. However, the zinc concentration at present poses little or no threat since zinc is an essential element and is required in reasonably higher amount than lead. If the activities continue to progress in an unregulated fashion, the heavy metal contents would escalate. This will engender a range of undesirable consequences. Crop productivity depends on soil quality since crops require certain $\mathrm{pH}$ levels for optimum yield. This implies that soil contamination by heavy metals would alter the soil $\mathrm{pH}$ and cause a shift in crop productivity and yield patterns. This will affect the agricultural output of the area because the local farmers with their subsistence orientation may not easily adapt to the changing crop productivity and yield pattern in the locality. This can cause settlement destabilization and displacement. Also, blastrelated vibrations have caused structural defects in buildings in the vicinity of the mine sites. The results of this study are consistent with some other reports of high heavy metal concentrations in the vicinity of mine sites [17, 20, 21]. However, the acidic content of the water samples in this result is higher than that reported by Alo et al. [17]. This is a demonstration that degradation gets worse with time as mining progresses without recourse to regulations and environmental consciousness

Table 2. Results of heavy metal concentration in $\mathrm{mg} / \mathrm{Kg}$ and $\mathrm{pH}$ of soil samples

\begin{tabular}{ccccc}
\hline Location & Source & Lead (Pb) & Zinc (Zn) & pH \\
\hline Ameka & Farm & 1.86 & 5.64 & 6.75 \\
Ohankwu & Farm & 1.59 & 0.57 & 6.74 \\
Abakaliki (Control) & Farm & 1.26 & 0.17 & 6.93 \\
\hline
\end{tabular}

\section{OTHER ASSOCIATED BIOPHYSICAL IMPACTS}

Generally, mining is an environmentally unfriendly activity and has thus attracted global attention from the stand point of its environmental ills. Environmental impacts produced by illegal mining activities in Nigeria are felt mostly by land and air resources, water resources, and socio-economic livelihoods.

\subsection{Land and air resources impacts}

Once an abandoned mining site is left un-reclaimed, the natural topography of the mined area is altered in ways that prevent return of the previous land use such as farming (see Figures 1-4). The denudation of the landscape causes reduction in soil fertility, low agricultural productivity and food shortage. The mining activity eliminates some existing vegetation and alters the soil profile. This de-vegetation causes soil erosion due to removed plant cover. In this way, the soil loses stability. There is also the disruption of drainage patterns, leading to flooding. Flowing waters from the mined areas have the tendency to carry much greater sediment loads, which together with erosion increase the likelihood of floods, fill the streams and ponds, and consequently resulting in more intense flooding. In the process of mining, some species are either destroyed or displaced from their natural habitats, thereby destabilizing ecosystem in the top soil. As highlighted in Section 4, surface mining exposes heavy metals and compounds that alter the $\mathrm{pH}$ of the immediate environment. Seepage forces can be sufficient to dislodge mineral grains from poorly cemented mineral fabrics such as loose sands and silts, and wash them out of the ground. This internal erosion reduces the support offered by the layers to the overlying 
materials. This could result in overburden collapse as some sort of landslide. Furthermore, dusts and particles from the mining sites are significant sources of air pollution. Sometimes, these illegal miners involve in removing fluids from subsurface formations and the detonations of explosives during rock blasts. These have the tendency of releasing preexisting stresses of tectonic origin. Seismicity induced by mining, fluid injection/extraction and reservoir loadings are the three main types of triggered seismicity affecting the preexisting stress field in different ways [22]. These are also potential causes of structural damage in the vicinity of the mining location. Figure 5 shows abandoned buildings in the vicinity of the mining area because of structural damage due to vibrations. This has caused some settlement destabilization in the area. Some of the abandoned mining sites developed into artificial lakes that were not even fenced off as danger zones (see Figures 4 and 6).

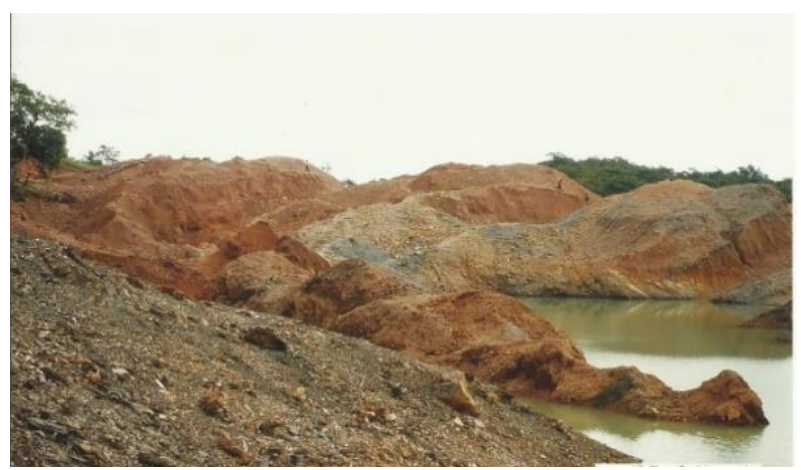

Figure 1. An unreclaimed surface mine with large accumulation of exposed infertile waste earth materials that can alter the $\mathrm{pH}$ of the environment

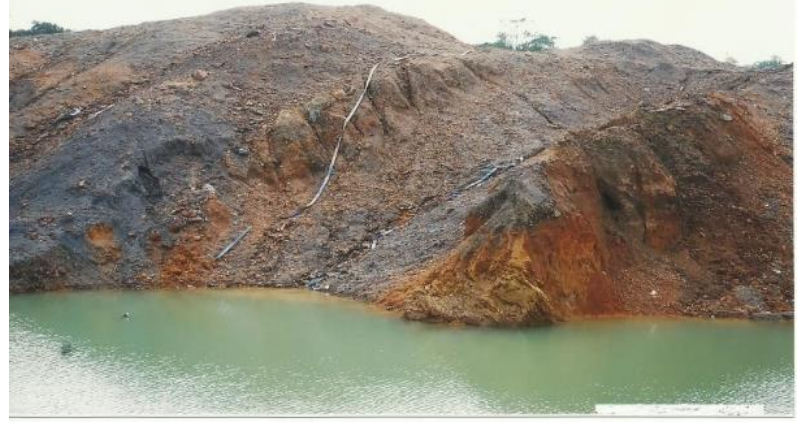

Figure 2. Shear volume of excavated earth materials that prevent the return of previous land use such as farming

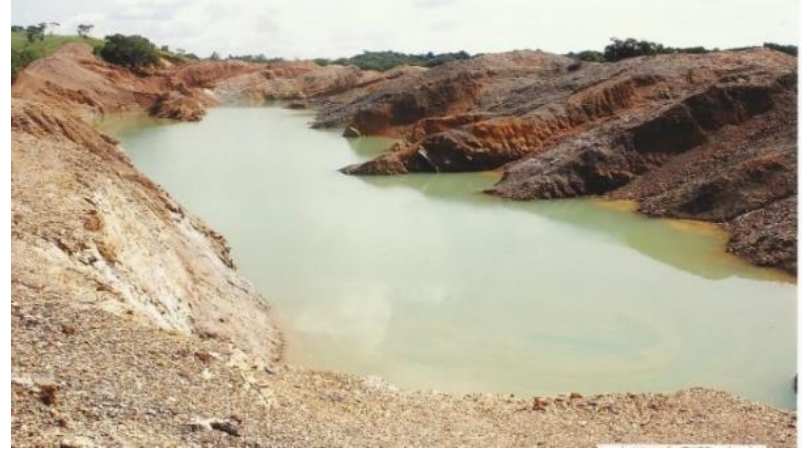

Figure 3. Denuded landscape that has altered the natural topography of the mine area with large water body entrapped

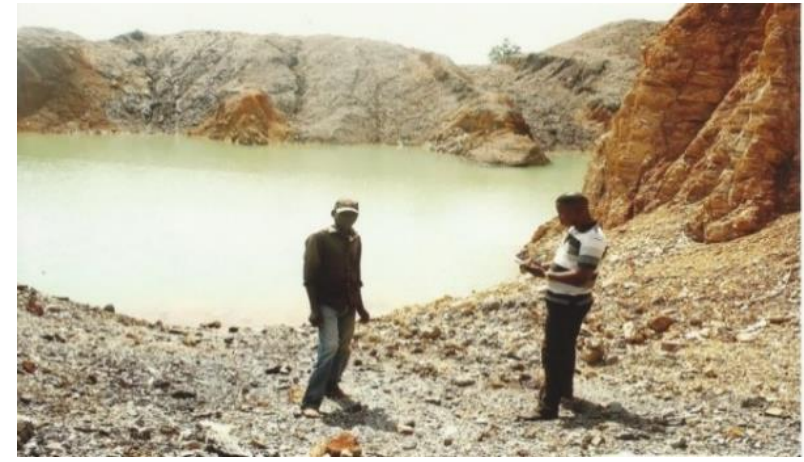

Figure 4. One of the researchers (right) interviewing an illegal miner in the mine area showing incidence of overburden collapse

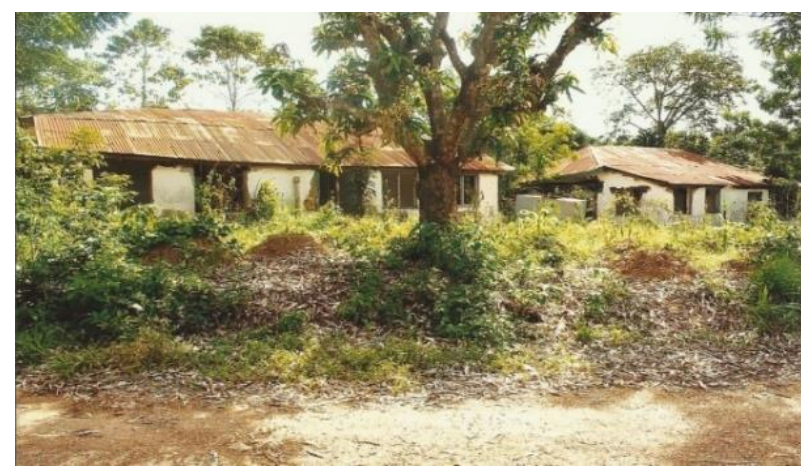

Figure 5. Abandoned buildings in the vicinity of the mine area occasioned by tremendous cracks due to vibrations resulting from mining operation

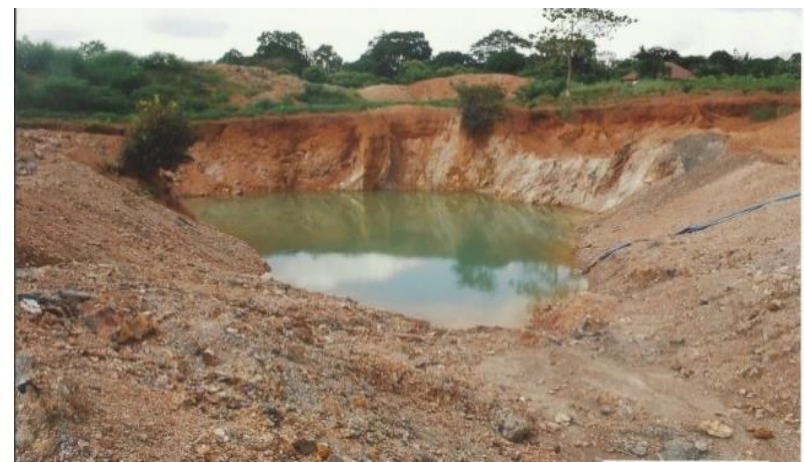

Figure 6. An unreclaimed abandoned surface mine that is developing into an artificial lake

\subsection{Water resources impacts}

Irresponsible mining causes erosion and water pollution. It disrupts and degrades water supply, increases water treatment and erosion control costs, and adversely affects breeding of sea foods. Some of the major pollutants are acid anhydrides, the heavy metals and suspended solids. Acids destroy fish and other aquatic lives, eat away metal structures, destroy concretes, thereby causing high incidences of building collapse and damage to the built environment. Acids may also leach out highly toxic substances which contaminate water supplies, causing adverse human health-related effects [4]. Suspended solids reduce light penetration in water by scattering and absorption of light. Consequently, the transparency and turbidity of the water bodies and water ways temperatures are altered. Mining activities also affect the 
quantity and quality of ground water supplies. In many cases, the mineral beds serve as aquifers (ground water-bearing formations). Flow patterns in these aquifers may be varied, thereby affecting water pressure in wells adversely.

Furthermore, potential impacts on ground water consist of the gradual and probable extension of the water-table core of depression (due to seepages) as mining proceeds. This impact would be limited to land within the mine buffer area and is not expected to affect ground-water or wells at off-site locations. Ultimately, groundwater extraction leads to changes in the groundwater condition in the mine area. Changes in existing stresses mainly through a decrease in vertical stress caused by a decreased pore pressure is a direct consequence of groundwater removal, and this can engender thrust faulting or folding in a thrust faulting environment where maximum effective stress is horizontal [22].

\subsection{Socio-economic impacts}

The contribution of illegal mining to development and sustenance of livelihood has triggered off some sort of debate. This is hinged on the premise that many poverty-stricken and hungry people (especially the youths) in rural areas see the occupation as a welcome solution to their financial predicament. To them, mining is the fast-lane process to their earthly riches. Therefore, the sector creates employment and generates income, leading to a better living standard and devoid of youth restiveness.

Nevertheless, even though a high proportion of the youths earn their living through this activity, the adverse impact is daunting. Threat to food security as a result of devastated expanses of fertile farmlands that are altered in ways that do not allow return of the previous land use such as farming is a major challenge (see Figures1-4). Rendering such arable land unfit for growing crops for several years hinders enormous food production. Years after the mines have been abandoned, the residual changes in soil physics, soil chemistry and water resources create difficulty in establishing a diverse and effective vegetative cover capable of self-regeneration. Suffice it to say that the disruption stemming from the mining constitutes an irreversible alteration of the area.

On the other hand, if the mining becomes highly prosperous, it brings about enormous influx of miners and the consequent creation of enclaves of overcrowded shanty and ghetto settlements. There would be increase in child labour involving many young boys and girls and many out-of-school children. This is common in the study area. As the business booms, substantial immigration results in increase in sexual trade, premature marriages, unwanted pregnancies, abortions, prevalence of sexually transmitted diseases (STDs) and spreading of deadly virus diseases such as the 'Corona' (COVID-19), 'Ebola', 'Lassa' fever and yellow fever etc.

\section{THE ASSOCIATED CHALLENGES}

\subsection{Tackling landscape denudation and improper closures}

Long-term damage to soil resources may be masked when intensive; short-term land management gives a false impression that attempt at reclamation has been successful. This portends risk and danger for structural establishments in the area in decades to come.
6.2 Lack of enforcement or non-adequate environmental legislation

Control and reclamation act and other enabling laws need to be enacted (where none exists) and enforced promptly (where some exist). The illegal miners are not unaware of the laws. As if they are protected by people in high places, they ignore the laws with impunity and believe that their activities are covered by the laws of the land.

\subsection{Difficulty in monitoring and enforcing environmental violations}

As a result of lack of resources (on the part of the law enforcement agents), the widely scattered and inaccessible nature of the terrains, the remoteness of the mining locations and the wide dispersion of the miners, they are very difficult to control and arrest. Oftentimes, the mining sites are several kilometers from the town without access roads. This has made legal measures inappropriate or inadequate as a means of control because the form of mining involved requires small and light equipment that are highly portable. This provides the miners good opportunities of evading control and arrests.

\subsection{Reckless abandon of the open-pit mines}

In most cases, there are careless abandon of the mines, some of which resulted in extensive excavations. Worse still, they are not even fenced off as danger zones. During flooding, these abandoned mining pits are filled with water to form large water bodies, which sizes depend on the depth of the targeted seam deposits and the extraction technique. This can get people drowned.

\subsection{Averting illegal mining in a manner that is devoid of youth restiveness}

Indulgence in illegal mining is attributed to lack of other economic opportunities. From their activities, it is clear that illegal mining is not likely to phase out unless there are other more viable economic opportunities within the mining community. Stopping them without appropriate programmes or palliative measures put in place could promote youth restiveness.

\section{SUGGESTED MITIGATION OPTIONS}

I. The government needs to synergize with local communities leadership in whose jurisdiction the mines are located. Building such synergy would promote healthy environmental management.

II. The existing government agencies and commissions saddled with responsibilities of environmental protection and mining should be sufficiently strengthened to live up to their responsibilities.

III. Enabling institutional framework should be built to promote policy formulation and capacitation, appropriate strategies, adequate legislation and co-ordinated mechanisms. This will ensure appropriate rehabilitation/reclamation and zero tolerance to unsustainable activities.

IV. Education is essential. There is the need to organize public awareness and environmental education programmes in schools. The community indigenes should be mobilized and 
sensitized through mass media and open crusades on the need to monitor their land, highlighting the consequences of their actions and inactions.

V. Environmental Impact assessment should be carried out prior to the commencement of any mining operation. A follow up to this is that environmental audits are carried out periodically to ensure compliance with regulatory requirements.

VI. Since most of the mining in Nigeria fall within the illegal category, the government could do well to put certain programmes in place to encourage these miners to graduate to small scale miners (SSM). Government should recognize them and put in place appropriate laws and policies guiding development and proper mining. Government should equally provide all necessary enabling environments that will make the operations succeed, including provision of pipe-borne water in the areas.

\section{CONCLUSION}

Illegal mining is an environmentally unfriendly activity and leaves on its toll grave environmental effects. These effects have health and biophysical dimensions. The results of the laboratory analyses of heavy metal contents of the water samples indicate that lead concentration in surface and subsurface water exceeds the maximum tolerable limit for domestic water by FAO and WHO standards. The high concentration of lead in mine water has grave health implications. If they gain access to the domestic water supply sources, it would exceed the maximum permissible limit recommended by $\mathrm{WHO}$ and FAO depending on the proximity of the mine pit to the domestic water sources. The zinc content of the water samples are, however, within the acceptable limit by WHO and FAO standards. The $\mathrm{pH}$ values of the water samples indicate acidic conditions that are well outside the range of permissible limits for domestic water by WHO and FAO standards. The heavy metal concentrations and the $\mathrm{pH}$ levels in the soil samples within the mine area are within the WHO permissible limits but higher than that of the control samples. It is recommended that periodic environmental audits are carried out and further researches need to periodically monitor and assess the soil and water contamination by heavy metal to ensure that they do not reach critical levels as mining progresses. This study was unable to empirically quantify the air quality degradation by aeresols consequent upon the mining operations due to lack necessary equipment. It was also unable to determine the amount of heavy metal accumulation in vegetables and crops got from the vicinity of the mine area. It is, therefore, recommended that future studies should quantify the impact of the mining on the air quality and heavy metal accumulation in vegetables and crops in the mining area. A number of mitigation measures have been recommended that could make legislation more productive or efficient with the government demonstrating strong political will and being proactive in decision and approach.

\section{REFERENCES}

[1] Palmer, M.A., Bernhardt, E.S., Schlesinger, W.H., Eshleman, K.N., Foufoula-Georgiou, E., Hendryx, M.S., Lemly, A.D., Likens, G.E., Loucks, O.L., Power, M.E., White, P.S., Wilcock, P.R. (2010). Mountaintop mining consequences. Science, 327(5962):

$148-149$ https://doi.org/10.1126/science.1180543

[2] Jaiye, D.J. (2013). The environmental implication of illegal mining activities in Nigeria, a case study of Pandogari and Barkin Ladi/Buruku surface mines in Niger/plateau states. IOSR Journal of Humanities Social Science $\quad$ (IOSR-JHSS), 13(5): 13-19. https://doi.org/10.9790/0837-1351319

[3] Adekeye, J. (2010). The Impact of Artisanal and Illegal Mining on the Environment in Nigeria. Center for Peace and Strategic Studies, University of Ilorin, Nigeria, 28p.

[4] Squillace, M. (2009). The Strip Mining Handbook. http://sites.google.com/site/strip mining handbook, assessed on Jun. 14, 2019.

[5] UNEP. (1996). Safety incidents concerning tailings dams at mines: results of a survey for the years 1980-1996 by Mining Journal Research Services, Report prepared for United Nations Environment Programme. Industry and Environment, Paris.

[6] He, Z.L., Yang, X.E., Stoffella, P.J. (2005). Trace elements in agroecosystems and impacts on the environment. Journal of Trace elements in Medicine and Biology, 19(2-3): 125-140. https://doi.org/10.1016/j.jtemb.2005.02.010

[7] Egila, J.N., Daniel, V.N. (2011). Trace metals accumulation in freshwater and sediment insects of Liberty Dam, Plateau State Nigeria. International Journal of Basic and Applied Sciences, 11(6): 128-140.

[8] Moore, F., Forghani, G., Qishlaqi, A. (2009). Assessment of heavy metal contamination in water and surface sediments of the Maharlu Saline Lake, SW Iran. Iranian Journal of Science and Technology (Sciences), 33(1): 4355

[9] Kishe, M.A., Machiwa, J.F. (2003). Distribution of heavy metals in sediments of Mwanza Gulf of Lake Victoria, Tanzania. Environment International, 28(7): 619-625. https://doi.org/10.1016/S0160-4120(02)000995

[10] Farkas, A., Salánki, J., Specziár, A., Varanka, I. (2001). Metal pollution as health indicator of lake ecosystems. International Journal of Occupational Medicine and Environmental Health, 14(2): 163-170.

[11] Authman, M.M., Abbas, H.H., Abbas, W.T. (2013). Assessment of metal status in drainage canal water and their bioaccumulations in Oreochromis niloticus fish in relation to human health. Environmental Monitoring and Assessment, 185(1): 891-907. https://doi.org/10.1007/s10661-012-2599-8

[12] Tchounwou, P.B., Yedjou, C.G., Patlolla, A.K., Sutton, D.J. (2012). Heavy metal toxicity and the environment. In Molecular, Clinical and Environmental Toxicology, 133-164. https://doi.org/10.1007/978-3-7643-8340-4 6

[13] Ogunbanjo, O., Onawumi, O., Gbadamosi, M., Ogunlana, A., Anselem, O. (2016). Chemical speciation of some heavy metals and human risk assessment in soil around two municipal dumpsites in Sagamu, Ogun State, Nigeria. Chemical Speciation and Bioavilability, 28(1-4): 142151. https://doi.org/10.1080/09542299.2016.1203267

[14] Liang, Y., Yi, X., Dang, Z., Wang, Q., Luo, H., Tang, J. (2017). Heavy metal contamination and health risk assessment in the vicinity of a tailing pond in Guangdong, China. International Journal of Environmental Research and Public Health, 14(12): 1557. https://doi.org/10.3390/ijerph14121557 
[15] Obasi, A.N., Obasi, S.E., Nwaeze, E., Amadi, S.O., Aloke, C., Alo, G.O. (2019). Heavy metal pollution and human risk assessment of farmlands around Enyigba lead-zinc mining site, Ebonyi State. Proceedings of the 4th World Congress on Civil, Structural and Environmental Engineering (CSEE' 19), Rome, Italy, pp. ICEPTP 135. https://doi.org/10.11159/iceptp19.135

[16] Obarezi, J.E., Nwosu, J.I. (2013). Structural controls of $\mathrm{Pb}-\mathrm{Zn}$ mineralization of Enyigba district, Abakaliki, southeastern Nigeria. Journal of Geology and Mining Research $5(11)$ : $250-261$ https://doi.org/10.5897/JGMR13.0189

[17] Alo, O.G., Obasi, N.A., Chukwu, K.E., Agu, A.N. (2016). Effects of lead-zinc mining activities on water and soil quality in Ameka mining area of Ezza South, Ebonyi State, Nigeria. International Research Journal of Natural and Applied Sciences, 3(7): 194-231.

[18] Adefolalu, A.D. (2002). Climate of Nigeria. Atlas of Nigeria, 65.

[19] Musa, J.J., Mustapha, H.I., Bala, J.D., Ibrahim, Y.Y., Akos, M.P., Daniel, E.S., Oguche, F.M., Kuti, A.I. (2017). Heavy metals in agricultural soils in Nigeria: A review. Arid Zone Journal of Engineering, Technology and Environment, 13(5): 593-603.

[20] Xiao, R., Wang, S., Li, R., Wang, J.J., Zhang, Z. (2017). Soil heavy metal contamination and health risks associated with artesian gold mining in Tongguan, Shaanxi, China. Ecotoxicology and Environmental
Safety,

141:

$17-24$

https://doi.org/10.1016/j.ecoenv.2017.03.002

[21] Anazoba, C.J., Eneji, I.S., Sha'Ato, R. (2019). Water quality and heavy metals contamination of artificial lakes in Heipang and Rayfield, Plateau State, Nigeria. Environmental and Earth Sciences Research Journal, 6(3): 112-118. https://doi.org/10.18280/eesrj.060303

[22] Matcharashvili, T., Chelidze, T., Peinke, J. (2008). Increase of order in seismic processes around large reservoir induced by water level periodic variation. Nonlinear Dynamics, 51(3): 399-407. https://doi.org/10.1007/s11071-007-9219-0

\section{NOMENCLATURE}

$\mathrm{mg} / \mathrm{Kg}$ milligramme per kilogramme. This is the unit used to express the mass of heavy metal present in one kilogram mass of the soil sample

$\mathrm{mg} / \mathrm{L}$ milligramme per litre. This is the unit used to express the mass of heavy metal contained in one litre of water sample.

$\mathrm{pH} \quad$ This denotes the degree of acidity or basicity of a solution. Acidity increases with decreasing values while basicity increases with increasing values. 7 is the neutral value. 